\section{School health services in Enugu East, Nigeria: perspectives from a resource- poor setting}

\author{
Adaobi I. Bisi-Onyemaechi, ${ }^{1}$ \\ Afonne N. Akani, ${ }^{2}$ Anthony N. Ikefuna, ${ }^{1}$ \\ Beckie N. Tagbo, ${ }^{1}$ \\ Josephat M. Chinawa, ${ }^{1}$ \\ Ugo N. Chikani ${ }^{1}$
}

${ }^{1}$ Department of Paediatrics, College of Medicine, University of Nigeria Enugu Campus; ${ }^{2}$ Department of Paediatrics, University of Port Harcourt Rivers State, Port Harcourt, Nigeria

\begin{abstract}
School health services (SHS) have widespread impact on the health of a large number of children with implications on access to primary health care especially in developing countries. The aim of this study was to assess health services in primary schools in Enugu East Nigeria. Thirty-three head teachers of primary schools in Enugu east Nigeria and officials of Ministry of Education were interviewed using a questionnaire adapted from school health evaluation scale. Four private schools had health personnel. Only six private schools had a health room. Two public schools had a functional first aid box. There were no health records available in any of the schools. School lunch was given by only one private school. Of a maximum of 45 , public and private schools had a mean score of 10.3 and 12.7 respectively on the school health evaluation scale $(\mathrm{P}=0.01)$. Three schools only attained the minimum acceptable score of 19. Health services are at a minimal level in primary schools in Enugu East Nigeria. A state school health policy should be developed through inter-sectoral collaboration of the relevant stakeholders to use the platform provided by schools to ensure access to primary health care and also act as bridge for more formal medical care for school children.
\end{abstract}

\section{Introduction}

Schools have direct contact with as much as $95 \%$ of children aged 5-17 years ${ }^{1}$ and therefore are best situated to improve their health in addition to educating them. School Health Services (SHS) are also necessary in order to keep the child in optimal health throughout his course of study, detect any departure from normal health and restore health as quickly as possible through immediate treatment in the school or appropriate referral. ${ }^{2}$ SHS provide data for monitoring, evaluating and improving child survival. This is even more important in developing countries like Nigeria where the school aged child is the survivor of high childhood mortality. ${ }^{3}$ Effective implementation of school health services would ensure a substantial level of access to primary health care for children. It ensures early detection of diseases that can impede learning, improve access to care for non-emergent conditions, improve nutritional status and control of communicable diseases in the community. The health of young people and the adults they eventually become is critically linked to the health-related behaviour they adopt early in life ${ }^{4}$ and SHS aims at inculcating healthy habits into the child which can be maintained through life by personal efforts. ${ }^{2}$

The realisation of these led to the launch of the National school health policy ${ }^{5}$ and implementation guidelines ${ }^{6}$ in Nigeria in 2006 and 2007 respectively. This policy is yet to be appraised likely due to lack of continuity in government policies experienced in Nigeria. It is also important to find out if these services exist in our schools, the level at which it operates where they exist and recommend ways of improving it. This study hopes to draw the attention of relevant stakeholders to the issue. The state also offers free primary and secondary education, a policy that has increased enrolment making more children accessible to education and health services. However, there is no data on health services in schools in this area that hosts such a large number of schools which can provide a good platform for improving child health statistics in the state.

The researchers set out to appraise school health services in Enugu East, to sensitize government on the need to step down the national school policy for the state and establish collaboration between the relevant stakeholders to ensure that schools act as a continuum of care for the child between the home and the community physician.

\section{Materials and Methods}

Study setting: Enugu is a mainland state covering 7,161, $\mathrm{km}^{2}$ in the South Eastern Nigeria with a population of 3.2 million. ${ }^{7,8}$

Sampling: Thirty three primary schools comprising 8 public and 25 private schools were selected from eight political wards in the local area using a systematic sampling method.

Ethical consent and approval: This was
Correspondence: Adaobi I. Bisi-Onyemaechi, Department of Paediatrics, College of Medicine, University of Nigeria, Enugu Campus, Nigeria.

Tel: +2348037082506

E-mail: adaobi.bisi-onyemaechi@unn.edu.ng

Key words: School health services; Enugu; Nigeria.

Contributions: AIB-O conceptualized and designed the study, collected the data and analysed it, drafted the initial and final manuscript and approved the final manuscript as submitted; ANA designed the data collection instrument, critically reviewed and revised the manuscript and approved of the final manuscript as submitted; ANI contributed to the design, supervised the data collection and critically reviewed and revised the manuscript and approved of the final manuscript as submitted; BNT critically reviewed and revised the manuscript and approved of the final manuscript as submitted; JMC contributed to the design of the study, critically reviewed and revised the initial manuscript and approved of the final manuscript as submitted; UNC critically reviewed and revised the manuscript and approved of the final manuscript as submitted.

Conflict of interest: the authors declare no potential conflict of interest.

Received for publication: 23 October 2016. Revision received: 27 February 2017.

Accepted for publication: 26 April 2017.

This work is licensed under a Creative Commons Attribution 4.0 License (by-nc 4.0).

(C) Copyright A.I. Bisi-Onyemaechi et al., 2017 Licensee PAGEPress, Italy

Healthcare in Low-resource Settings 2017; 5:6357 doi:10.4081/hls.2017.6357

obtained from Health Research and Ethics Committee of the University of Nigeria Teaching Hospital Enugu. Written consent was also obtained from the managing authorities of public and private schools in Enugu.

Data collection: The School health program (SHP) evaluation scale (Health services) was used to assess the schools. The first SHP evaluation scale was developed by Anderson and Cresswell, UK. ${ }^{4}$ This was modified by $\mathrm{Akani}^{2}$ to suit the Nigerian environment and level of economic development. It has three sections: school health services (used for this study), health instruction and healthful school environment. The subsections of SHS and the maximum marks allotted to them are personnel (4), appraisals (5), treatment facilities (5), care of emergencies (5), control of communicable disease (10), record keeping (6), nutrition services (7), and guidance and coun- 
selling (3). The scale has been used in SHS evaluation in Nigeria.9,10 The maximum score for school health services is 45 while the minimum acceptable score is 19 .

A questionnaire adapted from scale, reviewed by a panel of experts and pre-tested in two randomly schools in Enugu North local government council was administered to the head teachers of selected primary schools in the area. Scores were awarded to the responses given using the scale. Some officials involved in school and health administration in the state were also interviewed to ascertain their disposition to School health services in the state.

\section{Data analysis}

The data was analyzed using the statistical package for social sciences (SPSS) version 17. Data presentation was done with tables. The difference in the mean scores of school health services in private and public schools was compared using the Student ttest. The level of significance was set at a $\mathrm{P}$ value of less than 0.05 and confidence level at 95 .

\section{Results}

\section{General}

Eight public and twenty-five private schools were sampled. The schools had 304 teachers, 116 in the 8 public schools and 188 in the 25 private schools. The ages of the teachers ranged from 25 to 72 years. Four head teachers had Masters in Education, twelve had Bachelor's degree in Education, thirteen had National Certificate of Education, two, Higher National Diploma and two, Bachelor of Science. Two of the schools were located in farm settlements. Only eight of these head teachers had an idea of what school health services were but none of these could list its subcomponents. None of the administrators of schools in the state interviewed was aware of School health services and what it entails.

Twenty-seven $(81.8 \%)$ of the schools have periodic meetings with the parents while four do not. One head teacher did not respond to this question while one school had stopped the Parents Teachers Forum (PTF).

\section{Personnel}

There were no health personnel in any of the public schools. Four private schools had health personnel ( 2 nurses and 2 trained first aiders). The mean score for personnel for public schools was 0 while that of private schools was 0.24 out of a maximum of
$4(\mathrm{P}=0.97)$.

\section{Health appraisal}

Routine inspection was done by all the schools (public and private) while none of the schools sampled required pre-entry medical screening nor does periodic medical examination for the staff or students. Ten (30\%), two public, eight private schools refer ill children to nearby health facility. Seven schools (4 public, 3 private) had handicapped children who were given extra supervision but there were no screening test to detect handicaps. The mean scores for health appraisals were 1.44 and 1.75 for private and public school respectively, of a maximum of $5(\mathrm{t}=1.150, \mathrm{df}=31$ $\mathrm{P}=0.26$ ).

\section{Treatment facilities within the school}

All but two of the schools (both public) had a first aid box, however, five of the boxes were empty as seen in 4 public and I private school. Six schools (18\%), all private, had a health room/sickbay. Nine private schools only had a school bus. All but one public school had telephone services. The mean score for treatment facility within the public school was 2.63 while that of private was 3.52 of a maximum of 5 . $(\mathrm{t}=-3.06$, $\mathrm{df}=31, \mathrm{P}=0.01$ ).

\section{Care of emergency illness}

Twenty-four $(72.7 \%)$ of the schools, two public and twenty-two private, gave first aid while none recorded the treatment given. Twenty-seven ( 2 public, 25 private), $81.8 \%$, notified parents immediately of any emergency illness while ten ( 2 public, 8 private), $30.3 \%$ would transport an ill child to a nearby health centre. One public school located in a farm settlement would take the child home after treatment is given. The mean score for the public schools was 1.00 while that of private was 2.40 of a maximum of $5(\mathrm{t}=-4.523, \mathrm{df}=31, \mathrm{P}=0.00)$.

\section{Control of communicable diseases}

All the schools would send a child with a communicable disease home. Twentyseven schools ( 8 public, 19 private), $81.8 \%$, in addition, gave health talks to the children or the parents in the event of a communicable disease. Two schools (1 private, 1 public), had the facility to quarantine/isolate a child with communicable disease during the school hours while immunization services was lacking in all the schools. Mean scores for public and private schools were 2.13 and 2.04 respectively out of a maximum of 4 . $(\mathrm{t}=0.860, \mathrm{df}=31, \mathrm{P}=0.40)$.

\section{Record keeping}

The record of absenteeism was kept in all the schools but reasons for absence from school were not kept. Thirteen (11 private and 2 public) schools had forms given to parents on admission to fill out the health history of the child but these were neither available nor transferable. There were no available records of medical events like outbreaks of communicable disease. The record of absenteeism was available to the researchers at only twenty-one schools (4 public, 17 private). The available records of absence were cumulative in only four private schools but none was transferable. The mean scores obtained for both public and private schools were 0.5 and 1.08 respectively out of a maximum of $3(\mathrm{t}=-2.137$, $\mathrm{df}=31, \mathrm{P}=0.04)$.

\section{Nutrition services}

Nine schools ( 5 private, 4 public), had school farms. Nutrition demonstration was offered in only two schools (one public and one private) while only one private school offered school meals. None of the schools gave nutritional supplements. Mean scores for public and private schools were 0.03 and 0.28 respectively out of a maximum of 7 marks. $(\mathrm{t}=1-316, \mathrm{df}=31, \mathrm{P}=0.20)$ (Table 1$)$.

Three schools (all private) attained the minimum score of 19 for school health services.

The means for the public and private schools for school health services, out of a maximum of 45 is 10.36 and 12.76 respectively $(\mathrm{P}=0.01)$ (Table 2$)$.

The mean of the schools for school health services (public and private) is 12.18 \pm-2.46 , of a minimum of 19 . At a test value of $19, \mathrm{P}=0.01$.

\section{Factors affecting school health services}

Among the schools that do not request for medical report, nine (seven public, two private) said it was not in the curriculum, seven (one public, six private) said it was not necessary, six private schools thought it was expensive while four schools were not aware. The schools do not conduct periodic medical examination for the following reasons; not aware (19 schools), expensive (10 schools), not in the curriculum (9 schools), not necessary (3 schools), no appropriate personnel (one school), time wasting (1 school), new school (one school). School meals were not available in 32 schools for the following reasons; expensive (12), not necessary ( 8 schools), government not supportive ( 7 public schools), not in the curriculum (4 public and 1 private), against parents wish (4 private schools), no personnel (1 public and 1private). Two private schools felt having PTF meetings was not necessary, one private school said it never achieved any good result and stopped it while 1 public school said caregivers and 
parents do not respond to call for PTF meetings. Eighteen schools ( 3 public and 15 private) felt meeting with the host community was not necessary, five (1 public and 4 private) said it is expensive, three private school said it was a waste of time, three, not in the curriculum, one schools said it was new while one school gave no reason. Five public schools gave no form of treatment in the school because they had neither materials nor personnel to do so while two public schools had their community health centers opposite and adjacent to them and quickly referred cases there.

Thirty-one head teachers thought school health services was beneficial, one was not sure while one did not respond.

Interactions with officials of both ministries of Health and Education showed that none of them (Chairman UBE, Permanent secretary UBE, Director of schools Ministry of Education, Commissioner for Education, Director of Clinical services and Officer-in-charge of Research and training, Ministry of Health) had heard of or was aware of school health services. None was also aware of the existence of a National School Health Policy. The plan on board for the maintenance of the health of the school population was to provide and re-equip the first aid boxes in the public schools. There are no plans to train the teachers on any health issues but government was willing to welcome any such training at no cost to it. There were no health personnel in public schools because Ministry of Education could not afford it and Ministry of Health does not have enough personnel for it.

\section{Discussion}

There was non-uniformity in the qualification of the teachers and the explanation received was that tertiary education qualifies one to teach in primary school. This may also explain the poor awareness of school health services as some of them had no formal training in education. This has negative implications for child health because these teachers have the responsibilities of drawing attention to the child's condition and follow up of care, educating and counseling parents, carrying out the physician's requests and other activities to make the school more efficient. They are however ill-equipped to do these. This lack of awareness is in contrast to some other reports ${ }^{9-11}$ with awareness of up to $53 \%$ and $68 \%$, but similar to another study by Ofowe. ${ }^{12}$ It is not unexpected as the supervisors of these head teachers in the ministries are also not aware of SHS

Twenty three $(70 \%)$ of the schools had a functional PTF while five schools (public) have what is known as a School Based Management Committee (SBMC). This committee is made up of some prominent community leaders, some teachers and some parents who manage the affairs of the school. This SBMC found only in public schools was formed due to the non-chalance of parents to the welfare of the school and by extension, the school children, and also to increase the sense of belonging of the communities to the schools.

The absence of health personnel in all the public schools and majority of the private schools is similar to previous reports. ${ }^{9,10,13}$ Absence of health personnel was not perceived as a deficiency among the teachers. The head teachers would rather prefer training on basic elements of First aid and SHS as this would reduce the fear of mistakes as reported in one school. The reason for this was inadequate personnel as explained by an official of the Ministry of Health, lack of resources to pay personnel on the part of Ministry of Education and an apparent lack of cohesion between the Ministries of Education and Health in the state. This absence of health personnel in schools leaves health appraisals wholly in the hands of teachers whose competence may not be satisfactory. The result is that routine inspection of hair, teeth, nails and occasionally skin is the only form of appraisal done in all the schools.

This is also similar to previous reports, ${ }^{10,14-16}$ though one report showed that as much as $45 \%$ of schools had routine medical examination of students. ${ }^{12}$ Preentrance medical examination was not required by any of the schools. Some schools issue forms to parents to fill out their child's blood group, genotype etc. The parents fill these forms most times without a doctor's endorsement. The government has not provided any framework for medical screening of children before admission to reduce to the barest minimum obstacles to enrollment. This was reported by an official of the ministry of education. Pre-admission and periodic medical examination provides an opportunity to detect medical conditions that may prevent the child from benefiting maximally from this education and also to detect any underlying medical condition early before complications set in and this has not been uniformly implemented.

The finding of only children with motor physical challenge in the schools is not surprising as there was no evidence to support the ability of schools to manage children with other challenges like visual or hearing impairment or programs specifically designed to do so. The finding of first aid boxes in $94 \%$ of schools is consistent with other reports. ${ }^{9,10,16,17}$ However, the schools that did not have first aid boxes were public and four of the five empty boxes were found in public schools. They were said to be empty because contents were not replenished nor replaced. First aid was also administered by untrained school teachers in most private schools and this may have serious consequences if unaddressed. The public schools were poorly equipped for emergencies as none of them had a health room or a school bus. However, two public schools in the rural area of the local government were located opposite and adjacent to

Table 1. Mean scores of components of school health services.

\begin{tabular}{lccccc} 
& \multicolumn{2}{c}{ Public } & Service & \multicolumn{2}{c}{ Private } \\
& Mean & SD & Mean & SD & \\
Personnel & 0 & 0 & 0.24 & 0.23 & 0.97 \\
Health appraisal & 1.75 & 0.71 & 1.44 & 0.65 & 0.26 \\
\hline Treatment facility & 2.63 & 0.52 & 3.52 & 0.77 & 0.01 \\
Care of emergency & 1.00 & 0.76 & 2.40 & 0.76 & 0.001 \\
\hline Control of communicable disease & 2.13 & 0.35 & 2.04 & 0.20 & 0.40 \\
Record keeping & 0.50 & 0.53 & 1.08 & 0.70 & 0.04 \\
\hline Nutrition services & 0.03 & 0.01 & 0.28 & 0.15 & 0.20 \\
\hline
\end{tabular}

Table 2. Mean scores of school health services of public and private schools.

\begin{tabular}{|c|c|c|c|c|c|c|}
\hline & \multicolumn{4}{|c|}{ Service } & \multirow[t]{3}{*}{$\mathrm{t}$} & \multirow[t]{3}{*}{ P value } \\
\hline & \multicolumn{2}{|c|}{ Public } & \multicolumn{2}{|c|}{ Private } & & \\
\hline & Mean & SD & Mean & SD & & \\
\hline School health services (19-45) & 10.36 & 2.39 & 12.76 & 2.22 & -2.60 & 0.01 \\
\hline
\end{tabular}


the community health centre and referred all their medical cases there. Majority of the schools $(82 \%)$ found it more convenient to notify the parents immediately of any health challenge in their children for fear of mistakes and to reduce cost. The private schools that referred ill-children to health facilities had retainerships with them as had earlier been agreed with parents during PTF meetings.

All the schools practiced sending home a child noticed to have a suspected communicable disease on arrival in the morning. Even the two private schools with isolation rooms would be very unwilling to keep the child in school and would prevail on the parents to come and pick the child immediately. This is the practice as documented in other studies. ${ }^{9,10,16}$ The reasons attributed to this was fear of spread to other children and subsequent litigation. There are chances of sending the wrong child home or leaving a child incubating an infectious disease as the teachers may not have the expertise to differentiate an infectious from a non-infections disease. This strengthens the need for health personnel in the schools and training of school teachers on common communicable childhood illnesses. The poor recording of medical events noted here has also been reported in previous studies. ${ }^{9,15,16,18}$ The head teachers did not appreciate the need for such records and stated that there were no provisions for it by the supervising ministry.

Provision of school meals was available in one school where the cost was embedded in the school fees. This lack of school meals is also similar to the other reports. ${ }^{9,11,16,18}$ Most of the public schools appreciated the importance of school meals but admitted that government was not committed to the provision of free school meals. This was also confirmed by top officials of the Ministry of Education who affirmed that government alone cannot sustain the school meal service. Most of the private schools attributed lack of school lunches to the cost and objection of parents who would rather prepare meals eaten by their children. One public school had free school meal in the past before the collapse of the pilot phase of school meal service of the state government and an international organization. Information gathered revealed that the program failed in the state because of the lack of counterpart funding by the government. In Osun, South-west Nigeria, the school feeding program currently provides midday meals for elementary one to four children numbering 254,000 at present. There has been an increase of about $25 \%$ in school enrollment following this and a reversal of the low academic performance of children in public schools. Teachers also reported regular and punctual attendance to school, reduction in truancy and absenteeism, increase retention and participation in curricular activities. ${ }^{19}$ If sustained, this would contribute to achieving the sustainable development goals 1, 2,3,4,5 which address an end to hunger and poverty, improved nutrition, promotion of wellbeing at all ages, inclusive and quality education and measures to achieve gender equality and empowerment. Parents would be more willing to send their female children to school because of the added benefits of feeding. Malnutrition underlies more than $50 \%$ of all child mortality. ${ }^{20,21}$ School feeding program appears to be the most developed component in other countries. Ghana initiated its school health policy in 1992 and school feeding in 2005 and currently feeds about 1.7 million school children (37\% national coverage) and Togo about 20,000 children. ${ }^{22,23}$

The involvement of government in School Health Services has only been the initial provision of first aid boxes in $12 \%$ of the public schools. The fundamental problem of lack of awareness of SHS and its importance by the officials of the Ministries of Health and Education may also explain the present state of School Health Services in the state.

Concerted enquiries revealed that as at present, Enugu state is yet to have a school health policy. When these are in place, it is envisaged that School Health Services and child health by extension would improve dramatically in the state.

\section{Conclusions}

School health services are at a minimal level in Enugu East Nigeria, but are comparatively better in the private schools than public schools. The public schools were ill equipped to handle emergencies. Lack of awareness of school health services has contributed to the current state of health services in Enugu Schools. A state school health policy and a school health committee should be constituted in the state to aid and monitor the effective implementation of school health services. School districts should be created and nurses posted to such districts to visit specific schools on specific days. A transferable health card designed to keep information on the child's medical history, health appraisals and other health events should be issued on admission to every child.

\section{References}

1. Center for Disease Control and Prevention. Guidelines for school and community health programmes; promoting lifelong healthy eating; and overview. Atlanta, GA: CDC; 2001.

2. Akani NA, Nkanginieme KEO. The school health programme. In: Azubuike JC, Nkanginieme KEO (eds.) Pediatrics and child health in a tropical region. 2nd ed. Owerri: African Educational services; 2007. pp. 47-55.

3. Akani NA, Nkanginieme KEO, Oruamabo RS. The school health programme: a situational revisit. Nig J Paediatr 2001;28:1-6.

4. Anderson CL, Cresswell EH. School health practice. St Louis: The CV Mosby Company; 1980.

5. Federal Ministry of Health, Nigeria. National school health policy. Abuja: Federal Ministry of Health; 2006.

6. Federal Ministry of Education, Nigeria. Implementation guidelines of national school health policy. Abuja: Federal Ministry of Health; 2006.

7. Enugu State. Available from: https://en.wikipedia.org/wiki/Enugu_St ate

8. Enugu State. Available from: www.nigeriagalleria.com

9. Ezeonu CT, Akani NA. Evaluating school health appraisal scheme in primary schools within Abakaliki metropolis, Ebonyi State, Nigeria. Ebonyi Med J 2010;9:71684.

10. Mbaerie IA, Ofovwe GE, Ibadin MO. Evaluation of the performance of primary schools in Oredo LGA of Edo State in the SHP. J Commun Med Primary Health Care 2010;1:22-32.

11. Akani NA. The effect of a short term training of head teachers on the implementation of school health programme in primary schools in Obio/Akpor LGA. A dissertation in part fulfillment of the part II finals of the National Postgraduate Medical College of Nigeria. 1997.

12. Ofowe GE, Ofili AN. Knowledge, attitude and practice of school health programme among head teachers of primary schools in Egor LGA, Edo State Nigeria. Ann Afr Med 2007;6:99-103.

13. Imogie AO. An evaluation of primary healthcare in secondary schools in Oredo LGA of Bendel State. Nig School Health J 1987;7:99-104.

14. Ejifugha AU. Awareness of school health services among primary school teachers in Enugu state. Nig School Health J 1993;8:54-61. 
15. Ojugo AI. Status of health appraisal services for primary school children in Edo State Nigeria. Int Electr J Health Educ 2005;8:146-52.

16. Alex-Hart BA, Akani NA, Nkanginieme KEO. Evaluation of the school health services in Bonny LGA of Rivers State. Nig J Paediatrics 2008; 35:60-6.

17. Ogaji DS, Okokon EO. Appraising the physical environment of secondary schools in Calabar, Nigeria. J Environ Sci Toxicol Food Technol 2012;1:42-8.

18. Oduntan SO. The health of the Nigerian children of school ages 6-15 years. MD Thesis. London: University of London;
1972.

19. Akanmbi GO, Alayande E. Home grown school feeding and health program in Nigeria: an innovative approach to boosting enrolment in public primary schools. A study of Osun State 2002-2010. African Symp 2011;11:20-8

20. WHO Media Centre. Children: reducing mortality. Geneva: WHO; 2016.

21. Katz J, Lee AC, Kozuki N, et al. Mortality, risk in preterm and small-forgestational-age infants in low-income and middle-income countries 2013: a pooled analysis. Lancet 2013;382:41725.
22. Ghana Business News. Ghana launches national school feeding policy. Available from: https://www. ghanabusinessnews.com/2016/07/23/gh ana-government-launches-nationalschool-feeding-policy/

23. Andrews C, Galliano E, Turk C, Zampaglione G. Social safety nets in fragile states: a community based school feeding program in Togo. The World Bank 2012. Available from: https://openknowledge.worldbank.org/ bitstream/handle/10986/26829/646310 NWP011170BOX361542B00PUBLIC0.pdf? sequence $=1 \&$ isAllowed $=\mathrm{y}$ 